Article

\title{
High-skilled outsiders? Labor market vulnerability, education and welfare state preferences
}

\author{
Silja Häusermann ${ }^{1, \dagger}$, Thomas Kurer ${ }^{1, \dagger}$, and Hanna Schwander ${ }^{2, *, \dagger}$ \\ ${ }^{1}$ Institute of Political Science, Center for Comparative and International Studies (CIS), University of \\ Zurich, Zurich, Switzerland, and ${ }^{2}$ Centre for Social Policy Research, University of Bremen, Bremen, \\ Germany \\ *Correspondence: hanna.schwander@zes.uni-bremen.de \\ ${ }^{\dagger}$ Authors have equally contributed to the article; names are in alphabetical order.
}

\begin{abstract}
Recent research has established that employment risk shapes social policy preferences. However, risk is often conceptualized as an alternative measure of the socio-economic status. We show that employment risk and socio-economic status are distinct, crosscutting determinants of social policy preferences. More specifically, we analyze the policy preferences of high-skilled labor market outsiders as a cross-pressured group. We first establish that labor market vulnerability has spread well into the more highly educated segments of the population. We then show that the effect of labor market vulnerability on social policy preferences even increases with higher educational attainment. We conclude that that labor market risk and educational status are not interchangeable and that the high skilled are particularly sensitive to the experience of labor market risk. Thereby, our findings point to a potential cross-class alliance between more highly and lower skilled vulnerable individuals in support of a redistributive and activating welfare state. Thus, they have far-reaching implications for our understanding of both the politicization of insider/outsider divides and the politics of welfare support.
\end{abstract}

Key words: education, preferences, political economy, Europe, social policy, part-time employment JEL Classification: 12 P Unemployment benefits, J21 labor force and employment, size and structure, H53 government expenditures and welfare programs

\section{Introduction}

The link between individuals' situation in the labor market and their preferences for social policy has become a crucial area of research over the past few years (Rueda, 2007; Rehm, 
2009; Margalit, 2013), especially as labor market risks are increasingly unequally distributed between labor market insiders and outsiders (Rueda, 2007; Palier and Thelen, 2010; Emmenegger et al., 2012). However, labor market vulnerability is often too quickly assumed to be a close correlate of the socio-economic status in terms of education, skill level or income (Piore, 1980; King and Rueda, 2008). Put differently, outsiders are equated with 'cheap labor'. We question this assumption: given the stark expansion of employment in the typically less protected service sector, we argue that the distribution of employment risk is distinct from the distribution of skill in post-industrial societies. Indeed, we find labor market outsiders also among the high-skilled. In this article, we analyze the social policy preferences of highly educated individuals in vulnerable labor market positions as a cross-pressured group in Western Europe. ${ }^{1}$

Knowing the socio-structural profile and distributive preferences of high-skilled outsiders is crucial to understand the political consequences of the increasingly unequal distribution of employment risks. Our findings indeed point to an increasing potential for large pro-welfare alliances between higher and lower skilled vulnerable individuals in support of redistributive and activating social policy. Acknowledging the social policy preferences of the high-skilled yet vulnerable parts of post-industrial societies is particularly important, since these high-skilled outsiders - unlike lower skilled outsiders-are likely to be a politically informed and active group (Häusermann and Schwander, 2012), receptive to political mobilization. Our findings thus have far-reaching implications for our understanding of both the politicization of insider/outsider divides and the politics of welfare support.

We argue that highly educated individuals in vulnerable labor market positions are crosspressured regarding their social policy preferences: their high level of human capital enables them to perform well in the labor market. At the same time, they are only weakly integrated in the labor market, which prevents them from capitalizing on their earnings potential. In this article, we test which of these two determinants affects their social policy preferences more strongly.

Our argument regarding preference formation is based on a rational choice logic: people will be in favor of state intervention if they expect to gain from it (Meltzer and Richard, 1981; Moene and Wallerstein, 2003; Jaeger, 2006; Häusermann and Schwander, 2011). Regarding education, research has consistently shown a negative relationship between human capital and the demand for social policy. Individuals with low human capital prefer a generous, redistributive welfare state, whereas higher skilled individuals are more inclined to let the market determine labor market outcomes because their human capital pays off in the market. Putting forward another causal mechanism for the negative relationship between education and preferences for redistribution, Rehm and Kitschelt (2005) argue that education provides insurance against adverse labor market dynamics in post-industrial labor markets, thereby reducing the need for redistribution. Consequently, if anything, individuals with higher educational attainment should prefer a welfare state based on social insurance and the equivalence principle (Moene and Wallerstein, 2003).

The relationship between labor market vulnerability and the demand for generous and redistributive social policy, by contrast, is positive (Moene and Wallerstein, 2001; Walter, 2010; Fernàndez-Albertos and Manzano, 2011; Rehm, 2011b). Labor market outsiders need either compensation for their discontinuous labor market attachment in the form of redistributive policies or activation policies that support their integration into the labor market. Individuals with

1 Note that we use the notions of 'highly skilled' and 'highly educated individuals' interchangeably. 
stable and protected jobs, by contrast, benefit from a social insurance welfare state based on contributions, because they have full and complete contribution records that entitle them to high benefits.

To analyze how education and employment risk influence social policy preferences, we proceed in two steps. We first show empirically that insider/outsider divides and education are crosscutting: atypical forms of employment are also common among certain highly educated segments of the labor force. However, one may question whether atypical employment among the highly skilled is indeed related to labor market disadvantages (which the notion of 'outsiderness' implies), or whether it is just an unproblematic, flexible form of employment. Hence, we subsequently demonstrate that labor market vulnerability is associated with labor market disadvantages in terms of income, job satisfaction, replaceability, and training opportunities also among the highly educated. In a second step, we examine the preferences of the cross-pressured group of highly educated outsiders with regard to three distributive principles of social policy: redistribution, activation and social insurance. In contrast to existing studies, we do not analyze preferences for 'more' or 'less' welfare state, but preferences for distinct distributive principles of the welfare state.

Our article demonstrates that labor market vulnerability has a clear positive effect on preferences for redistribution and activation and a clear negative effect on social insurance preferences, whereas education has exactly the opposite effect. Furthermore, we find that labor market vulnerability matters even more for explaining social policy preferences among the high-skilled than among the low-skilled. In other words, high-skilled outsiders are particularly sensitive to the experience of labor market risk.

The article is structured as follows: we first discuss why labor market vulnerability has spread into the highly educated middle class. We then present our argument about the social policy preferences of high-skilled but vulnerable individuals as a cross-pressured group. Ensuing we demonstrate that a substantial part of the high-skilled indeed is confronted with adverse labor market dynamics and show that this exposure is linked to actual disadvantages in the labor market. We then examine the impact of labor market vulnerability and education on social policy preferences, separately and jointly. The final section summarizes the findings and discusses their implications for the literature on welfare state support, insider/ outsider divides and comparative political economy.

\section{Labor market vulnerability among the highly educated}

In this section, we explain first why employment vulnerability in the post-industrial economy affects not only the lower skilled but also skilled and even highly skilled workers. We present our argument about the conflicting influences of labor market vulnerability and education on social policy preferences.

\subsection{The highly educated in increasingly unstable labor markets}

The dominant view within the literature conceptualizes dualization as a divide within the working class. This implies that many key contributions to this literature associate outsiders with low income and low skill, and others explicitly exclude upscale groups from the analysis (as for example Rueda, 2006, 2007). King and Rueda (2008) equate outsiderness with 'cheap labor' and call the outsiders the 'employment underclass'. In their discussion of a trade-off between cheap standard labor and cheap outsider labor, they focus explicitly on low-pay, low- 
benefit and low-protection jobs, as this is 'the standard for almost all non-standard employment' (King and Rueda, 2008, p. 280). Also, in the original formulation of the theory of segmented/dual labor markets, jobs in the secondary labor market are assumed to be characterized by unpleasant work conditions and to require low or no skills (Piore, 1980). The assumed correlation between outsider status and low skill level is also particularly pronounced in contributions examining the link between migration and dualization (Piore, 1980; King and Rueda, 2008; Emmenegger and Careja, 2012).

To be clear, we do not argue that skill levels or educational attainment are irrelevant for the individual level of risk exposure or that higher skilled individuals face the very same labor market risks as lower skilled individuals. Indeed, labor market prospects have become dire for lower skilled workers as cognitive skills are more crucial than ever in dealing with the rising complexity of jobs in modern economies (Murnane et al., 1995; Carbonaro, 2007). The decline in jobs with medium skill levels additionally increases competition for lower skilled jobs as parts of the middle-skilled workers are forced to compete for these jobs, too (Autor et al., 2003; Goos and Manning, 2007). Nevertheless, labor market vulnerability is spreading to the skilled workforce as a consequence of the massive growth and heterogenization of the educated middle class in the post-war period. Three socio-economic trends have been driving this massive expansion of middle-class employment: the tertiarization of the employment structure, the educational revolution and the expansion of the welfare state (Oesch, 2006, p. 7). The increase in service sector employment was both driven and supported by the expansion of higher education, which promoted a wide array of professional and managerial occupations and hence a broader middle class (Crouch, 1999). This resulted in an increased heterogeneity within the highly educated middle class in terms of work settings and labor market positions across Europe (Kriesi, 1993; Müller, 1999). Equally, the employment conditions of skilled and high-skilled occupations of a larger and more heterogeneous middle class have diversified. A skilled whitecollar occupation is no guarantee of employment security and high income any more. In particular, service sector jobs at all skill levels involve more atypical, non-standard or discontinuous employment (Oesch, 2006). As the European welfare model is built on the premise of permanent full-time employment, weak labor market integration or deviation from the standard model of employment (i.e. full-time, permanent employment) results in risks of income and welfare losses. Consequently, we consider atypical employment forms as vulnerable.

Socio-structurally, gender and age stand out when thinking about these highly skilled yet vulnerable groups. ${ }^{2}$ Women's labor market attachment has traditionally been less stable than men's. They are particularly likely to belong to these highly skilled yet vulnerable groups, especially in Continental and southern Europe (Esping-Andersen, 1999, 2009; Fellini and Migliavacca, 2010; Schwander and Häusermann, 2013). For women in

2 There is a clear relation between the spread of outsiderness (not only among the high-skilled) and what has been called 'new social risks' (Bonoli, 2005; Taylor-Gooby, 2005), because they originate in the same structural processes: an increasingly post-industrial social structure and labor market clashes with labor markets and welfare states that have been built in and for the industrial age. This explains why atypical work creates particular risks of insufficient social policy coverage. However, the new social risk literature is mainly concerned with new poverty risks for low-skilled risk groups. 
Continental Europe, for example, atypical employment is the norm rather than the exception, regardless of their educational level (Esping-Andersen, 1999, 2009). Similarly, young adults encounter a variety of labor market risks when entering the labor market, especially unemployment or temporary work (Esping-Andersen, 1999, 2009; Chauvel, 2009; Ranci, 2010). The current employment crisis in Europe exacerbates the difficulties for young workers to find a stable job even in the longer run of their careers. In 2011, youth unemployment (15-25 years) in the European Union was at $22 \%$ and $31.3 \%$ of the young adults under the age of 30 had a non-permanent contract (OECD, 2012, p. 14; for temporary work: EU-SILC, 2012; ${ }^{3}$ own calculations). Part of the labor market vulnerability of young adults results from their lack of work experience. However, labor market institutions, such as strong employment protection legislation and the importance of internal labor markets in the hiring process can exacerbate the labor market vulnerability of young adults (Gangl, 2001, 2003). ${ }^{4}$

Hence, young adults and women might experience labor market vulnerability despite high skill levels. In the next section, we present our argument about the repercussions of this crosspressure between labor market vulnerability and human capital.

\subsection{The crosscutting impact of labor market vulnerability and education on social policy preferences}

Our theoretical arguments are based on the premise that welfare state preferences are mainly shaped by economic self-interest. Hence, the main reason for diverging preferences lies in the distributive implications of social policies. ${ }^{5}$ Social rights are either based on employment or on need (social insurance versus redistribution) and have different goals (activation versus passive protection). In this section, we discuss how labor market vulnerability and education affect social policy preferences. In particular, we argue that the effect of labor market vulnerability on support for social policy should be even stronger among the high-skilled than among the low-skilled: among the low-skilled, generalized support for the welfare state is likely to be high for insiders and outsiders for a number of reasons (such as lower levels of income and wealth), with labor market vulnerability being just one more factor that pushes in the same direction. However, among the high-skilled, general support for welfare state generosity is lower. Hence, they should be less inclined toward expansive policies, unless they are in a vulnerable labor market situation.

Insiders and outsiders have different social policy preferences because welfare policies affect them in distinct ways. The crucial distinction between labor market insiders and outsiders is (in)stability of employment. Social insurance favors insiders given their full

3 European Survey on Income and Living Conditions, http://epp.eurostat.ec.europa.eu/portal/page/ portal/microdata/eu_silc

4 Following these considerations, it has often been argued that a flexibilization of employment protection would smoothe labor market entry (Scarpetta, 1996; Lindbeck and Snower, 2001). In practice, however, most labor markets underwent a mostly 'selective flexibilization,' leaving the privileges of core workers untouched (Regini, 2000). Indeed, the massive use of temporary contracts is seen as a reason for the unstable position of young adults in southern Europe itself (Polavieja, 2006).

5 An alternative approach assumes that welfare state preferences are also shaped by cultural norms and values. Beliefs about the deservingness of welfare beneficiaries, social mobility, luck as a determinant of economic success and religious orientations influence these norms (Linos and West, 2003; Bénabou and Tirole, 2006; Scheve and Stasavage, 2006; van Oorschot, 2006). 
contribution records and stable employment careers. ${ }^{6}$ By contrast, individuals who have paid only irregularly or low contributions to the social insurance systems due to unstable employment do not qualify at all or only for low benefits. Hence, the main preference divide in terms of the insider/outsider differentiation is straightforward: insiders favor employment- and insurance-based social policies that grant social rights and benefits according to contributions, while outsiders prefer redistributive social policies, which allocate rights and benefits on the basis of need. Hence, outsiders prefer compensation for their discontinuous and tenuous labor market attachment in the form of needs-based redistribution (H1a). At the same time, we expect a negative relationship between outsiderness and support for social insurance (H1b).

Welfare states also differ with regard to whether they aim at passively compensating individuals for income loss or at activating the beneficiaries. While activation can be achieved in a punitive 'workfare' logic through cutting benefits and lowering social minima, we think here of non-punitive activation policies that are in the interest of outsiders. These policies enhance opportunities for employment or reduce barriers for labor market entry by means of training, education, child care and active labor market policies (Bonoli and Natali, 2012). Such policies support labor market integration, thereby representing an alternative to needs-based redistribution. Outsiders should be particularly inclined to these policies, because stable and continuous access to the labor market is exactly what they lack. Hence, we expect a positive relationship between labor market vulnerability and support for activation (H1c).

Although we expect the relationship between labor market vulnerability and social policy preferences to hold across the entire workforce, we also argue that the effect of labor market vulnerability interacts with education levels and is particularly strong among the higher skilled. The previous section has argued that education and labor market vulnerability are crosscutting. We expect social policy preferences to differ between higher and lower skilled outsiders, because their labor market prospects and their specific social policy needs are not the same. High-skilled individuals have both the cognitive resources and the marketable skills to perform well in the labor market once they have the opportunity to make use of their human capital. We therefore expect a positive interaction effect between outsiderness and education levels on support for activation policies $(\mathrm{H} 2 \mathrm{a})$. An example may help illustrate this idea. Imagine a young university graduate who cannot find a stable job and an unemployed supermarket cashier. Both are exposed to strong labor market risks. We assume that the former wants to make use of her education in the labor market, whereas the latter is concerned with covering his daily expenses with income from whatever source, be it labor market income or social transfer payments.

Regarding redistribution, we hypothesize that individuals with lower skill levels find it hard to earn a sufficient income through the market even if they have a stable job, given that they are generally disadvantaged in post-industrial labor markets. Hence, even lower skilled insiders may support redistribution. The more highly educated, however, have a higher earnings potential, which should make them less inclined toward redistribution unless they are in a vulnerable labor market position (this is where the cross-pressure is most evident). Hence, we expect the higher educated to support redistribution only if they are in a vulnerable labor market position. Consequently, we hypothesize that the level of

6 Another reason insiders favor social insurance systems is because they feel they have 'earned' the benefits through their contributions (Palier, 2002). 
education reinforces the effect of labor market vulnerability on support for redistribution, the lower skilled being more similar in their social policy preferences than the high-skilled (H2b).

Similarly, we predict a reinforcing interaction effect of education with regard to the impact of outsiderness on social insurance preferences $(\mathrm{H} 2 \mathrm{c})$. As outlined before, individuals with higher education have a higher earnings potential, which also results in higher contributions to social insurance schemes and, accordingly, higher benefits. For lower skilled and lower paid workers, on the other hand, social insurance is always a problematic deal, as the expected benefits are proportional to their low earnings.

Our argument about the high-skilled individuals as a cross-pressured group has far-reaching consequences for the study of welfare politics and the politicization of insider/outsider divides. Whereas dualization and insider/outsider divides in policy preferences are portrayed as a conflict within the working class, our article reveals that these developments do not stop short of the middle class. Hence, our findings highlight the potential of a cross-class alliance of vulnerable individuals with different educational backgrounds in support of a redistributive and activating welfare state. Since higher skilled outsiders are likely to be politically active and engaged (see Häusermann and Schwander, 2012), this affects the politics of welfare states and also the potential of a politicization of insider/outsider divides. In this sense, our argument relates to a recent contribution by Rehm et al. (2012) on the effects of unemployment risk and income on social policy support. They find that support for unemployment insurance is higher in countries where unemployment is less concentrated among the poor. While testing their argument at the macro level, they implicitly make an assumption about the preferences of middle-income earners as a cross-pressured group. In this article, we shed light on the micro-foundations of such an argument.

There is an alternative explanation for the support of some high-skilled social groups for generous social policies that we want to address. Both the preferences and attitudes of these people, as well as the occupational profile they have chosen may be explained by an unobserved third variable, in particular post-materialist values or specific socialization processes in the family and so on. A post-materialist value orientation embraces values like social justice, equality and solidarity with the weaker members in society (Inglehart, 1977). One might thus expect post-materialists to be more supportive of the welfare state than materialists, a hypothesis for which Gelissen (2000) provides empirical evidence. In a similar vein, Scheepers and Grotenhuis (2005) find that post-materialists are more likely to donate money for poverty alleviation. The question of the direction of causality between the labor market position of an individual and his/her attitudes is a relevant and open one (Kitschelt and Rehm, forthcoming). Self-selection may indeed to some extent be an alternative or additional mechanism for explaining the link between vulnerability and preferences, especially since vulnerability among the high-skilled is concentrated among certain social groups. ${ }^{7}$ However, even though it might well be the case that certain individuals self-select into structurally more vulnerable occupations, vulnerability as such still poses a problem for them, and we assume that they would still favor measures to ease this problem. Even if the occupational class was self-selected, vulnerability is not the choice the individuals made, which is why we think that the direction of the causal link between risk and preferences remains plausible.

7 We cannot empirically test this alternative in the absence of panel data, but we do introduce control variables for post-materialistic or culturally liberal values in the regressions. 


\section{Empirical analysis}

The structure of the empirical analysis is as follows: we first show that labor market vulnerability is not unfamiliar to certain segments of the high-skilled population. In accordance with the concept of outsiders as a structurally disadvantaged segment of the workforce, we present evidence for the incidence of atypical employment among high-skilled individuals and show that labor market vulnerability is related to actual disadvantages in the labor market, even for high-skilled individuals. In a second step, we examine the effects of labor market vulnerability and education on social policy preferences.

\subsection{The incidence of atypical employment among highly skilled women and young adults}

To show that labor market vulnerability affects specific segments of the highly educated as well, we compare the labor market vulnerability among the highly educated with the one among the entire workforce by discussing the incidence of the three most common forms of employment risk-temporary employment, involuntary part-time employment and unemployment. Based on the EU-SILC survey 2007, Table 1 displays the rates of temporary work for the entire workforce, for the high-skilled and for the two high-skilled sub-samples we expect to be particularly vulnerable: young adults aged between 18 and 40, and women. ${ }^{8}$ Higher education is defined as post-secondary or tertiary educational degree. About a third of all respondents are counted as highly educated. ${ }^{9}$ We chose 40 as the age threshold because most European countries still have a considerable part of young adults in education at the age of 30 (Couppié and Mansuy, 2003). Considering that acquiring a firm position in the labor market takes another couple of years, a substantial share of people in their thirties must still be counted as labor market entrants. Highlighted fields indicate groups with a rate exceeding the one observed in the overall workforce. Table 2 shows the same information with regard to involuntary part-time employment for the same groups, ${ }^{10}$ and Table 3 refers to unemployment.

Overall, Tables 1-3 confirm that high-skilled individuals are not particularly exposed to labor market risks in comparison with the entire workforce (first two columns). The only labor market risk that high-skilled workers are confronted with is temporary employment, but only in half of the countries under consideration (see Table 1). However, the columns referring to the potentially vulnerable segments of the high-skilled workforce show that these segments are indeed exposed to labor market vulnerability. For example, the third column

8 We deliberately use pre-crisis data to show that the structural patterns of employment risk are not just a short-term result of the crisis. Since 2008, the economic crisis has exacerbated employment risks among the young in particular.

9 The proportion of higher skilled individuals in the ESS 4 and ESS 5 surveys, which we use in later parts of the analysis, is roughly the same.

10 We define part-time employed as voluntarily part-time employed if the respondent answered 'I do not want to work more hours' when asked for the reasons of their part-time employment. While this definition corresponds to the standard definition of involuntary part-time in the insider-outsider literature (see Rueda, 2005, p. 63) 'outsiders are then defined as those [. . .] employed part-time (unless they do not want a full time job'), the OECD defines involuntary part-time differently (see http://stats.oecd.org/ glossary/detail.asp?ID=2016). Employing the OECD definition leads to a lower rate of involuntary parttime employment. 
Table 1 Rates of temporary employment of different segments of the workforce, by country

\begin{tabular}{lcccc}
\hline & $\begin{array}{l}\text { Entire } \\
\text { workforce }\end{array}$ & $\begin{array}{l}\text { High-skilled } \\
\text { workforce }\end{array}$ & $\begin{array}{c}\text { High-skilled } \\
\text { aged 18-40 }\end{array}$ & $\begin{array}{c}\text { High-skilled } \\
\text { women }\end{array}$ \\
\hline Austria & 7.9 & 6.0 & 10.2 & 7.3 \\
Belgium & 13.8 & 11.9 & 17.1 & 14.2 \\
Switzerland & 8.8 & 8.2 & 10.8 & 10.4 \\
Germany & 11.2 & 11.8 & 18.4 & 14.2 \\
Denmark & n.a. & n.a. & n.a. & n.a. \\
Spain & 35.7 & 26.2 & 38.4 & 31.4 \\
Finland & 16.5 & 13.4 & 23.9 & 17.8 \\
France & 18.7 & 14.5 & 21.1 & 16.5 \\
Greece & 24.7 & 18.2 & 26.5 & 21.1 \\
Ireland & 11.0 & 10.6 & 13.2 & 13.0 \\
Italy & 17.7 & 17.8 & 27.2 & 21.0 \\
Netherlands & 11.3 & 11.8 & 16.4 & 13.2 \\
Norway & 12.5 & 12.0 & 18.4 & 14.8 \\
Portugal & 23.3 & 23.9 & 43.5 & 24.2 \\
Sweden & 16.6 & 16.9 & 25.5 & 18.6 \\
United Kingdom & 4.3 & 5.2 & 6.3 & 5.6 \\
\hline
\end{tabular}

Notes: Boldface groups are groups with a higher rate of temporary employment than the national workforce. Source: Own calculation, based on data from the EU-SILC, 2007.

of Table 1 shows that temporary employment is an employment reality for young adults with post-secondary or tertiary education: in all countries, high-skilled individuals aged between 18 and 40 have higher rates of temporary employment than the entire workforce. This does not surprise, as temporary work has often been used as a means of transition from school to work. Young labor market entrants start with fixed-term contracts in the early phase of their career to gain work experience and then move on to a permanent contract. ${ }^{11}$ However, the increased use of temporary contracts over the past decades has extended the phase of job insecurity beyond the initial phase of labor market access over a longer career period (Ranci, 2010). Thus, as employers are more reluctant to employ new employees on permanent contracts, it has become more difficult for younger cohorts to acquire a stable position even in the medium and long run of their careers.

Furthermore, Table 2 suggests that not only temporary work but also involuntary parttime employment affects young high-skilled adults. While in Denmark, Greece and Italy parttime employment is more widespread among young high-skilled adults than among the entire workforce, it is still quite frequent in the other countries. For example, almost $39 \%$ of young adults work part-time in the Netherlands, whereas in Switzerland and Germany more than $20 \%$ of high-skilled young adults work part-time. Additionally, as the third column in Table 3 shows, highly educated young adults in Italy and Greece are more often unemployed than the entire workforce $(7.0 \%$ and $7.3 \%$, respectively). Despite the fact that the rate of

11 If we only consider young adults at the age of 25 to 40 , their rates of temporary employment are lower but still exceed the average rate of temporary employment in the vast majority of countries. 
Table 2 Rates of involuntary part-time employment of different segments of the workforce by country

\begin{tabular}{lrccc}
\hline & $\begin{array}{l}\text { Entire } \\
\text { workforce }\end{array}$ & $\begin{array}{l}\text { High-skilled } \\
\text { workforce }\end{array}$ & $\begin{array}{l}\text { High-skilled } \\
\text { aged 18-40 }\end{array}$ & $\begin{array}{l}\text { High-skilled } \\
\text { women }\end{array}$ \\
\hline Austria & 18.9 & 16.8 & 18.6 & 32.0 \\
Belgium & 20.6 & 17.9 & 17.1 & 29.9 \\
Switzerland & 29.4 & 24.7 & 22.2 & 46.0 \\
Germany & 24.3 & 22.4 & 23.4 & 41.1 \\
Denmark & 13.3 & 13.8 & 11.8 & 22.3 \\
Spain & 9.8 & 8.2 & 10.7 & 13.0 \\
Finland & 11.0 & 7.0 & 7.6 & 9.5 \\
France & 16.3 & 14.5 & 15.3 & 23.0 \\
Greece & 9.4 & 7.6 & 10.5 & 10.4 \\
Ireland & 19.9 & 16.2 & 15.7 & $\mathbf{2 6 . 3}$ \\
Italy & 10.8 & 10.4 & 13.3 & $\mathbf{1 6 . 7}$ \\
Netherlands & 39.0 & 38.7 & 38.9 & $\mathbf{6 5 . 9}$ \\
Norway & 10.6 & 8.4 & 8.5 & $\mathbf{1 4 . 8}$ \\
Portugal & 7.8 & 6.0 & 7.7 & 7.6 \\
Sweden & 21.0 & 18.1 & 18.2 & 26.8 \\
United Kingdom & 16.9 & 15.3 & 14.6 & 25.3 \\
\hline
\end{tabular}

Notes: Boldface groups are groups with a higher rate of involuntary part-time employment than the national workforce.

Source: Own calculation, based on data from the EU-SILC, 2007.

Table 3 Rates of unemployment of different segments of the workforce by country

\begin{tabular}{lcccc}
\hline & $\begin{array}{l}\text { Entire } \\
\text { workforce }\end{array}$ & $\begin{array}{l}\text { High-skilled } \\
\text { workforce }\end{array}$ & $\begin{array}{l}\text { High-skilled } \\
\text { aged 18-40 }\end{array}$ & $\begin{array}{c}\text { High-skilled } \\
\text { women }\end{array}$ \\
\hline Austria & 4.4 & 2.5 & 3.5 & 3.4 \\
Belgium & 8.4 & 4.0 & 4.1 & 4.3 \\
Switzerland & 1.2 & 0.7 & 0.9 & 0.7 \\
Germany & 8.0 & 5.4 & 3.8 & 6.7 \\
Denmark & 1.5 & 1.4 & 0.8 & 1.7 \\
Spain & 9.2 & 5.2 & 6.8 & 6.7 \\
Finland & 3.3 & 1.7 & 1.8 & 1.9 \\
France & 6.4 & 4.0 & 4.8 & 4.3 \\
Greece & 6.1 & 4.9 & 7.0 & 6.8 \\
Ireland & 5.7 & 2.9 & 3.5 & 2.7 \\
Italy & 5.9 & 4.4 & 7.3 & 5.3 \\
Netherlands & 0.6 & 0.4 & 0.3 & 0.4 \\
Norway & 1.1 & 0.6 & 0.9 & 0.6 \\
Portugal & 7.7 & 4.1 & 6.4 & 4.2 \\
Sweden & 1.8 & 1.2 & 1.4 & 1.0 \\
United Kindom & 2.3 & 1.3 & 1.8 & 1.3 \\
\hline
\end{tabular}

Notes: Boldfaced groups are groups with a higher rate of unemployment than the national workforce. Source: Own calculation, based on data from the EU-SILC, 2007. 
unemployment among young adults does not exceed the national average in Spain and Portugal, a substantial share of young adults are unemployed in these countries $(6.8 \%$ and $6.4 \%$, respectively). In southern Europe, the rates of unemployment, part-time and temporary employment of young adults with post-secondary or tertiary education exceed the national averages, indicating that the rigid labor markets in southern Europe do not spare young adults with higher education. This confirms previous findings that the transition from university to work is most protracted in southern Europe (Blanchflower and Freeman, 2000; Pozzoli, 2009; Ranci, 2010). We would like to emphasize that this refers to the time before the unemployment crisis hit southern Europe. Since 2007, the employment situation has deteriorated especially for younger workers (World Bank, 2013).

With regard to the labor market vulnerability of high-skilled women, the tables show that high-skilled women face a high risk of involuntary part-time and temporary work but less so of unemployment. The general gender bias of part-time employment is echoed in higher involuntary part-time rates among high-skilled women in all countries but Finland, Portugal and Greece (see last column in Table 2). Most scholars explain this with the need to reconcile family and work in the absence of affordable child care facilities (O'Reilly and Fagan, 1998; Esping-Andersen, 1999, 2009). Also, in many countries, temporary work is more widespread among highly educated women than among the workforce in general. In Belgium, Spain, Portugal, France and Greece, the rates of female temporary employment do not exceed the country average, but temporary employment is still frequent with rates between $14.2 \%$ and $31.4 \%$ (see Table 1). This corresponds to the findings of Fellini and Migliavacca that women have lower access to stable (i.e. open-ended) contracts than men and that unstable employment is more strongly feminized than overall employment throughout Western Europe (Fellini and Migliavacca, 2010). Hence, high-skilled women often work in atypical employment, but their human capital largely seems to shield them from unemployment.

Three conclusions can be drawn from the numbers discussed here. First, labor market vulnerability is not confined to the low-skilled but affects segments of the highly educated workforce as well, namely young and female workers. Second, we have seen that labor market vulnerability among the highly educated results first and foremost from temporary work (in the case of young and female high-skilled) and involuntary part-time work (in the case of highskilled women). Third, we find that the incidence of labor market vulnerability among young high-skilled and among female high-skilled individuals varies between countries, probably due to differences in labor market institutions, welfare states and educational systems. As implication for the further empirical analysis, we conclude that we need to control for composition effects by including gender, age and country dummies as additional variables.

\subsection{The effects of atypical employment on labor market disadvantages and preferences}

In this section, we demonstrate that labor market vulnerability leads to objective and subjective disadvantages in the labor market for the highly educated and test whether it affects their social policy preferences.

To assess the effects of atypical employment, we construct a composite measure of labor market vulnerability as an independent variable that takes the different forms of atypical employment into account. We call this variable 'outsiderness'. The degree of outsiderness is the risk of being unemployed or in atypical employment (involuntary part-time employment, 
temporary employment or helping in family business). For every respondent, we quantify this risk on the basis of the frequency of unemployment and atypical employment within his or her occupational class (for an extensive discussion and validation of this measure, see Schwander and Häusermann, 2013). Similarly to Rehm's work on unemployment risk, we rely on occupational classes for the measurement of risk, because the probability of experiencing unemployment or atypical employment is very unequally distributed across occupational classes (Rehm, 2011a). We use the class scheme by Oesch in the collapsed version of Rehm and Kitschelt (2005). They distinguish five occupational classes: capital accumulators (highskilled managers, self-employed and experts), socio-cultural professionals (high-skilled professionals in the public and private service sector), blue-collar workers (unskilled and skilled workers mostly in the industry), low service functionaries (unskilled and skilled employees in interpersonal services) and mixed service functionaries (routine and skilled clerks). We further distinguish those five classes according to gender and age. As before, the age threshold is set at 40 .

The combination of five classes, two sexes and two age groups leaves us with 20 occupational groups, which are the basis of our measurement. We compute the rates of unemployment, involuntary part-time employment and temporary employment ${ }^{12}$ from data of the EU-SILC survey 2007 for each occupational group and the average workforce in every country. ${ }^{13}$ We then subtract the average rate of the national workforce from the group-specific rates to obtain the group-specific deviations (over- or underrepresentation) in unemployment, involuntary part-time and temporary employment. The reason for subtracting the national average from the group-specific value lies in the relational nature of labor market risks. A group-specific unemployment rate of $10 \%$ has a different meaning in a country with an average unemployment rate of $5 \%$ than in a country with a national unemployment rate of $15 \%$. The average of these three standardized deviations indicates the value of labor market vulnerability, that is, the degree of outsiderness of each occupational group in each country. Occupational groups with a lower labor market vulnerability than the entire workforce have negative values of outsiderness, whereas groups with an over-proportional labor market vulnerability have positive values of outsiderness. We then attribute the value of his or her occupational group to each respondent of the European Social Survey (ESS) data sets we use.

As we would expect from Tables 1-3, labor market vulnerability as measured by our variable outsiderness is not distributed equally across the occupational groups: female and young labor market participants experience atypical employment more often than men and elderly employees. In all countries, young female low-skilled service employees have the highest risk, and elderly male capital accumulators have the lowest risk of atypical employment and unemployment (see Schwander and Häusermann, 2013). For this article, it is particularly important to note that the high-skilled are not shielded from labor market vulnerability.

12 Due to their low proportion (1.2\% of respondents), we refrained from constructing a separated category for 'helping in family business' and added them to the category of temporary employment.

13 We do not calculate the values of outsiderness directly in the ESS data for one main reason: the number of cases. The number of respondents (3500-8500 respondents for each country) in the EU-SILC household panel thus allows for a precise measurement of labor market vulnerability across countries even for those groups which are naturally small (such as old female blue-collar workers, for example), which is even more important since we rely on labor market conditions that may affect very small portions of the workforce only. 
Roughly between $25 \%$ and $40 \%$ of the high-skilled belong to groups experiencing positive values of outsiderness. In other words, at least $25 \%$ of high-skilled respondents have rates of unemployment and atypical employment that lie significantly above the national workforce average (see Supplementary Appendix Figure A.1), in many countries substantially more (e.g. Belgium, Switzerland, Germany, Denmark, Spain, France, Netherlands and UK). ${ }^{14}$ High-skilled outsiderness is particularly concentrated among female socio-cultural professionals and mixed service functionaries.

As we argued before, the dominant view within the dualization literature is that the privileged segments of the working force are not affected by atypical employment. Our analysis refutes this view: atypical employment is widespread also among the highly skilled. Yet one might argue that even then high-skilled atypically employed are not outsiders in the sense that their labor market vulnerability is associated with disadvantages in the labor market. Rather, atypical employment might be seen as an unproblematic expression of a flexible and mobile labor force. We use the presented measure of labor market vulnerability and indicators of subjective labor market disadvantage and lower job quality to show that atypical employment has real negative effects on labor market outcomes even for the high-skilled. We use two indicators for subjective labor market disadvantages: job satisfaction and satisfaction with the household income. Objective lower job quality is also measured by two indicators: the replaceability of an individual at his or her workplace and the possibility to improve his or her knowledge or skills since outsider jobs tend to be characterized by little security or career advancements (Piore, 1980). We expect even high-skilled outsiders to fare worse than insiders on all indicators.

The analysis is based on data from the ESS 5 from 2010, including 14 countries. ${ }^{15}$ Job satisfaction is measured by means of a question asking respondents how satisfied they are with their main job (their answers are coded on an 11-point scale). The respondent's feeling about their household income (ranging from 'very difficult to get by' to 'living comfortably') is our second indicator of subjective labor market disadvantage. We measure objective job quality with two variables as well: the first question asks about replaceability, that is, respondents evaluate how long it would take someone with the right qualifications to do his or her job right (with answers ranging from 1 'one day or less' to 8 'more than five years'). The last indicator we use refers to the possibility of updating skills and knowledge in the current job by asking whether the respondent had the possibility to improve his or her skills or knowledge in the past 12 months. Both variables indicate how the respondent feels about his or her chances for career advancement and value for the employer: employers are more interested in retaining and investing in employees that are difficult to replace. Employees with low replaceability are indeed less concerned about their job security (Goldthorpe, 2000; Emmenegger, 2009). In addition, prospects for career advancement should be lower for employees who are easy to

14 In addition, the box plots in the Supplementary Appendix show that the variance of the outsiderness variable is relatively similar per country for the high- and low-skilled respondents. The variance between countries obviously differs, but the box plots show that high-skilled outsiderness is not concentrated in a few countries only.

15 Belgium, Denmark, Finland, France, Germany, Greece, Ireland, the Netherlands, Norway, Portugal, Spain, Sweden, Switzerland and the UK. We include all countries available both in the EU-SILC and ESS data. 
replace or who undergo less on-the-job or vocational training. A detailed operationalization of all variables is described in Supplementary Appendix 1.

As we want to show the effect of outsiderness on these different dependent variables at varying levels of education, Figure 1 presents marginal effects of labor market vulnerability at different levels of education. The results of the underlying ordinary least squares (OLS) and ordered logistic regressions, which include a range of control variables that may affect both outsiderness and labor market (dis)advantages, as well as country fixed effects are shown in Supplementary Appendix 2.

Figure 1 clearly demonstrates that an increase in labor market vulnerability is significantly and consistently related to lower labor market outcomes among the high-skilled respondents. When it comes to subjective job satisfaction and feeling about household income, the marginal effect of labor market vulnerability is even significant only among the more highly educated. We assume this to be the case because the low-skilled are generally more strongly disadvantaged, hence, the variance in labor market disadvantages is lower among the low-skilled. To give an idea of the substantive impact of labor market vulnerability, we calculate the predicted probability to be satisfied with job and income for a high-skilled individual with the highest and lowest value of outsiderness. ${ }^{16}$ This respondent's probability to be fairly or completely satisfied with her main job (values 7 and higher on the 11 -point scale) is $57 \%$ if she is a maximum outsider compared to $80 \%$ if she has the lowest value of labor market vulnerability. With regard to satisfaction with household income, the difference for the same individual with highest and lowest value of labor market vulnerability is 10.5 percentage points.

Similarly, the bottom part of Figure 1 shows that labor market vulnerability is associated with lower job quality. This holds for the entire workforce, even for the highly educated subgroup. The higher the labor market vulnerability a respondent is exposed to, the lower he or she estimates the time span that it would take someone to do his or her job right and the lower the chances to improve their skills. In substantive terms, the probability that a maximum outsider with tertiary education estimates the time it would take to replace her to be at least a year is only $7 \%$. On the contrary, the same probability is $33 \%$ for the same individual with the lowest value of outsiderness. Similarly, highly educated yet vulnerable respondents fall behind their insider peers in the chances they got to improve their knowledge or skills in the past 12 months by $21 \%$. Again, these findings suggest that labor market vulnerability is associated with lower job quality and higher insecurity in the labor market even for the highly educated.

In sum, high-skilled outsiders seem to be afflicted with labor market disadvantages in both subjective and objective terms, despite-or maybe because of - their high levels of human capital resources.

We argue that labor market vulnerability has a particularly strong effect on social policy preferences for the cross-pressured group of highly skilled outsiders. To reiterate, we expect labor market vulnerability to have a positive effect on preferences for redistribution and activation but a negative effect on support for social insurance (H1). We hypothesized further that the effect of labor market vulnerability on social policy preferences increases with increasing

16 All other variables are held at their median: A 41-year-old woman who works in the private sector, lives in a relationship, attends religious services once a year, is not a union member, has an income within the seventh income decile, agrees that gays and lesbians should live as they wish and lives in Germany. 

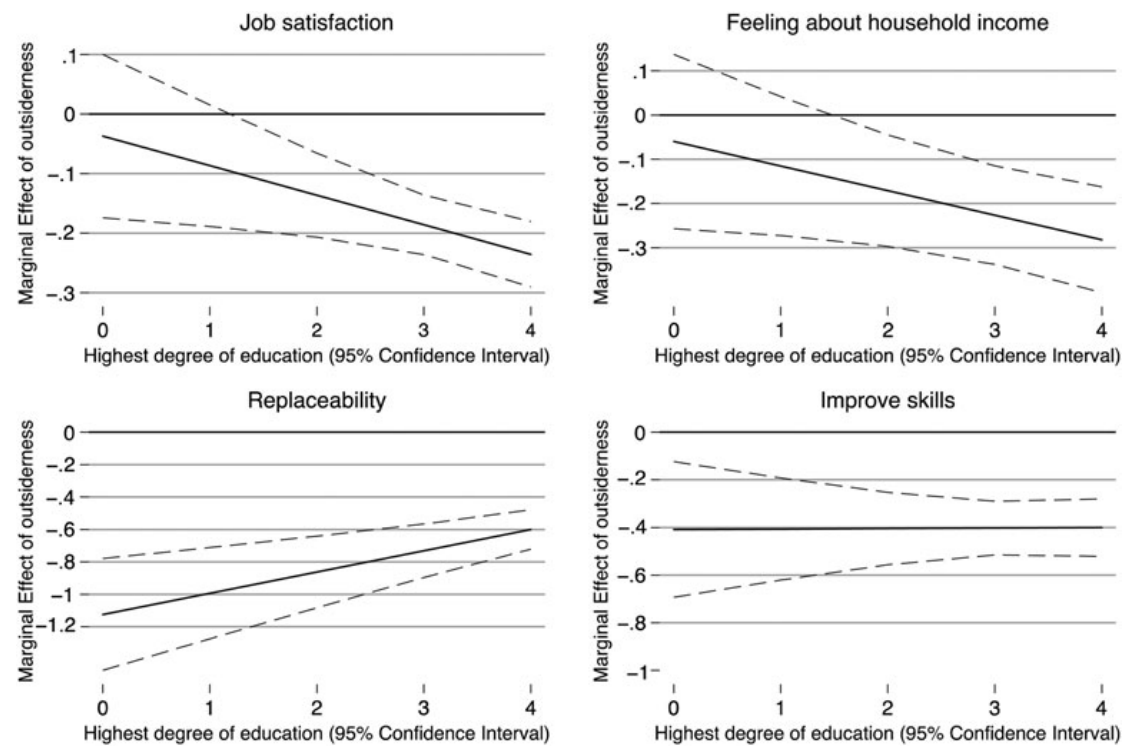

Figure 1 Marginal effects of outsiderness on labor market disadvantages at varying levels of education.

educational attainment because the high-skilled are cross-pressured, whereas the low-skilled generally support generous welfare benefits due to a range of factors $(\mathrm{H} 2)$. Again, we test our expectations by modeling an interaction effect between labor market vulnerability and education levels. ${ }^{17}$ The analysis is based on data from the ESS 4, 2008, because it contains specific questions that allow differentiating between different social policy principles. Data are available for 13 countries. ${ }^{18}$

Preferences for the different distributive principles are our dependent variables. Preferences for redistribution are measured on a 5-point scale asking respondents whether they think that the government should reduce income differences, which is a commonly used variable to measure redistribution preferences. Regarding preferences for activation, we use a question that asks whether the government should provide a job for everyone who wants one (measured on a 11-point scale), as this variable clearly focuses on employment instead of passively compensating income loss. ${ }^{19}$ Finally, preferences for the equivalence principle of the social

17 We present the findings for the pooled country sample in the text, but Figures A.2-A.4 in the Supplementary Appendix provide the marginal effects graphs for each country. Given lower case numbers per country and country specificities, results vary to some extent, but the results we find in the pooled analysis are robust in their structure in a clear majority of countries for all three dependent variables. We also calculated all models sequentially excluding countries one by one to test for strong effects of particular countries, and the results remained robust throughout.

18 The same countries as before minus Ireland, which is not included in the ESS 2008.

19 The literature on activation social policies has identified different types of activation policies. One important differentiation is between positive, enabling activation policies and punitive workfare activation. Activation policies can be further differentiated according to their emphasis on human capital investment and pro-market employment orientation, respectively (Bonoli, 2013). Since we want to 
insurance state are measured by a variable that asks respondents whether they think individuals who have contributed more to the pension system should be entitled to higher benefits (as opposed to individuals in greater need being entitled to higher benefits). To the best of our knowledge, this is one of the only two comparatively available questions to capture the difference between needs- and employment-based social policy. Each variable is recoded so that higher values reflect stronger support for the specific distributive principle. We include household income ${ }^{20}$ a dichotomous variable measuring whether a person lives in a couple household, public employment and union membership as control variables. To control for the influence of cultural values on welfare state preferences, we also control for church attendance and cultural liberalism (De La O and Rodden, 2008; Rehm, 2009, 2011a, b). ${ }^{21}$ Based on the insights of our previous analysis, we include gender, age and country fixed effects to control for compositional effects of labor market vulnerability.

Table 4 presents the estimates for the determinants of social policy preferences. For each dependent variable we specified two models, one that tests the linear relationship between outsiderness and preferences, and one that includes an interaction term for outsiderness and education levels.

Let us first briefly discuss the linear effects. Models 1 and 3 show that labor market vulnerability is linked to higher support for redistribution and activation, and Model 5 indicates that labor market vulnerability is associated with lower support for social insurance. This corresponds exactly to our first set of hypotheses: due to their weaker labor market attachment, outsiders favor redistribution and activation, whereas insiders are supportive of social insurance. Turning to our second variable of theoretical interest, we find that education has a negative effect on support for redistribution, which is again in line with the expectations we draw from the literature. Education also affects preferences for public job creation negatively, probably due to the overall better chances of individuals with higher educational attainment in the labor market (Shavit and Müller, 1998; Carbonaro, 2007; Oesch and Rodriguez Menes, 2011). By contrast, higher educational attainment is associated with higher support for social insurance. Hence, the linear models in Table 4 confirm that the effects of education and outsiderness are consistently countervailing.

We now turn to the interaction effects between labor market vulnerability and educational attainment. Figure 2 shows the marginal effects of outsiderness on preferences at different

measure outsider-friendly activation, our choice of variable - capturing the general principle of positive activation and employment creation-is well suited. A further differentiation, however, as well as a contrast to punitive activation is impossible due to data constraints.

20 Since we have list-wise deletion of missing data in our analyses, controlling for income makes us lose about $20-25 \%$ of the cases. We have re-calculated the models without the income variable to test for a possible bias, and the results are consistently robust.

21 Controlling for cultural liberalism should allow us to exclude that the support for welfare state policies is just a consequence of more broadly „post-materialist“ values. The ESS does not allow for operationalizing the Inglehart-postmaterialism index. However, we have tested a range of alternative measurements of cultural liberalism: support for equal gay rights (shown in the tables), support for law and order (whether people who break the law should get harsher sentences) and gender equality (whether women should be prepared to cut down work for the family) and a composite measure of all three. We only report the results for the first indicator in the text, but all results are robust to the different specifications. 


\section{Table 4 Determinants of welfare state preferences}

\begin{tabular}{|c|c|c|c|c|c|c|}
\hline & \multicolumn{2}{|l|}{ Redistribution } & \multicolumn{2}{|l|}{ Job creation } & \multicolumn{2}{|l|}{ Social insurance } \\
\hline & M1 & M2 & M3 & M4 & M5 & M6 \\
\hline Outsiderness & $0.203 * *(0.02)$ & $0.011(0.10)$ & $0.214 * *(0.06)$ & $-0.021(0.05)$ & $-0.193 * *(0.05)$ & $-0.038(0.07)$ \\
\hline Education & $-0.111 * *(0.02)$ & $-0.104 * * *(0.02)$ & $-0.100 * * *(0.01)$ & $-0.091 * * *(0.01)$ & $0.112 * * *(0.04)$ & $0.107 * * *(0.04)$ \\
\hline Outsiderness $\times$ education & & $0.065^{* *}(0.03)$ & & $0.081 * * *(0.03)$ & & $-0.053 *(0.02)$ \\
\hline Female & $-0.088(0.05)$ & $-0.101 *(0.05)$ & $-0.013(0.05)$ & $-0.029(0.05)$ & $0.185 *(0.07)$ & $0.195 *(0.07)$ \\
\hline Age & $0.001(0.00)$ & $0.002(0.00)$ & $-0.002(0.00)$ & $-0.002(0.00)$ & $0.002(0.01)$ & $0.001(0.01)$ \\
\hline Income & $-0.135 * *(0.02)$ & $-0.133 * * *(0.02)$ & $-0.083 * *(0.01)$ & $-0.081 * * *(0.01)$ & $0.083 * * *(0.02)$ & $0.082 * * *(0.02)$ \\
\hline Public sector employment & $0.226 * *(0.03)$ & $0.223 * *(0.03)$ & $0.190 *(0.08)$ & $0.186 *(0.08)$ & $-0.086 * *(0.03)$ & $-0.085 * *(0.03)$ \\
\hline Living with a partner & $-0.131 *(0.06)$ & $-0.128 *(0.06)$ & $-0.049(0.04)$ & $-0.044(0.04)$ & $0.027(0.03)$ & $0.025(0.03)$ \\
\hline Union membership & $0.330 * *(0.05)$ & $0.329 * * *(0.05)$ & $0.191 * * *(0.04)$ & $0.190 * * *(0.04)$ & $-0.110 * * *(0.03)$ & $-0.109 * * *(0.03)$ \\
\hline Church attendance & $-0.051 *(0.03)$ & $-0.050 *(0.03)$ & $-0.037(0.04)$ & $-0.037(0.04)$ & $0.031(0.03)$ & $0.030(0.03)$ \\
\hline Cultural liberalism & $0.187 * *(0.05)$ & $0.188 * * *(0.05)$ & $-0.031(0.06)$ & $-0.030(0.06)$ & $-0.066(0.04)$ & $-0.067(0.04)$ \\
\hline Pseudo $R^{2}$ & 0.142 & 0.143 & 0.101 & 0.103 & 0.198 & 0.199 \\
\hline$N$ & 18709 & 18709 & 18701 & 18701 & 18191 & 18191 \\
\hline
\end{tabular}

Notes: Values in parentheses are standard errors. Ordered logistic regressions with clustered standard errors and country dummies; country dummies and cut-points not shown; pseudo $R^{2}$ is the McKelvey and Zavoina $R^{2}$; population and design weights are applied; *significant at the 0.1 level, * significant at the 0.05 level, ***significant at the 0.01 level.

Data source: ESS 42008. 

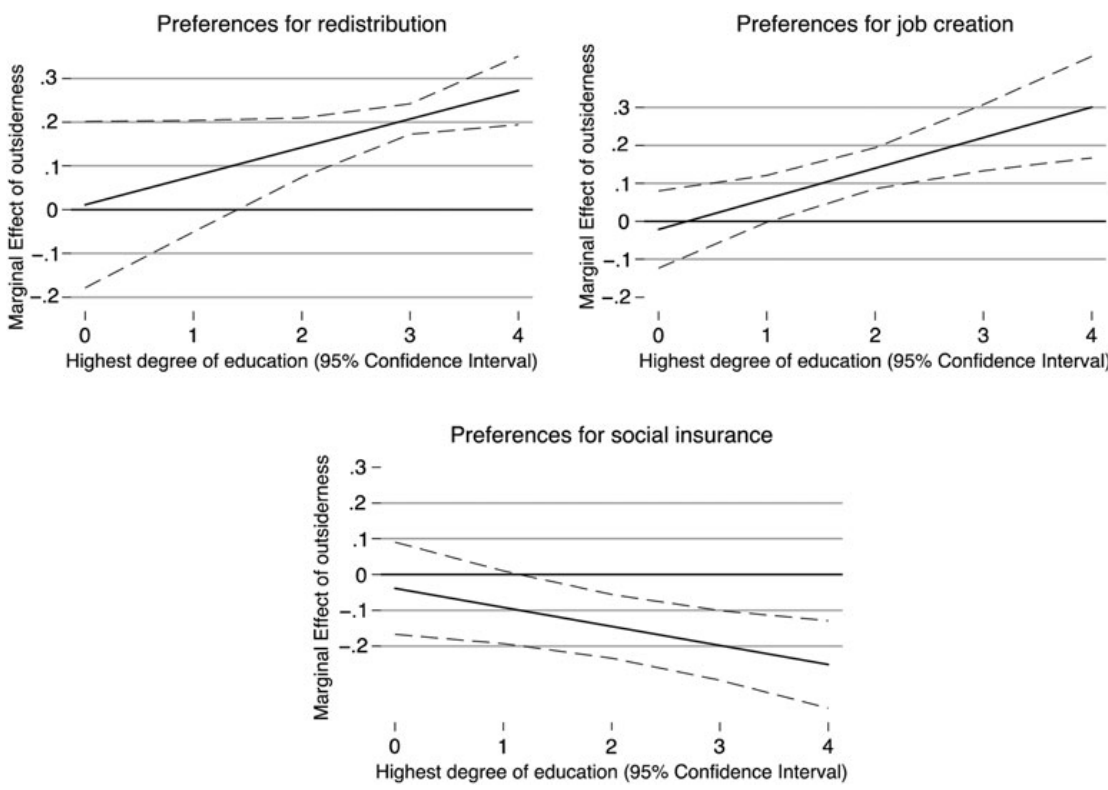

Figure 2 Marginal effects of outsiderness on social policy preferences at varying levels of education.

levels of education and thus provides a detailed picture of the conditions under which the interaction is significant.

Regarding preference for redistribution, the marginal effect of outsiderness is positive and significant, but only for respondents with an upper secondary degree or higher (which, however, represent a majority of respondents, about $67 \%$ ). Below that level, labor market vulnerability has no effect on preferences for redistribution. This finding concurs with Hypothesis $2 \mathrm{~b}$ : we argued that the preferences of the lower skilled are more similar than the preferences of the higher skilled because even low-skilled insiders should favor redistribution for reason of the generally low income of low-skilled workers. In other words, among the low-skilled, the effect of education prevails over the effect of outsiderness. The high levels of support for redistribution among all low-skilled respondents further bolster this argument: the probability of a low-skilled individual supporting redistribution is $68.3 \%$ with a significant difference between insiders and outsiders of 15.4 percentage points. ${ }^{22}$ Among the high-skilled, support is generally lower $(55.2 \%)$, but the difference within the high-skilled group based on the level of outsiderness is higher: an individual with the highest value of labor market vulnerability has a likelihood of $65.4 \%$ to support redistribution, whereas the same probability is 18 percentage points lower for a high-skilled individual experiencing the lowest level of outsiderness.

22 All other variables being held at their median, that is, a 48-year-old women, who is neither a public employee nor a union member, lives in a relationship, rarely goes to church, agrees that gays and lesbians should live as they wish and lives in Germany. Low-skilled means a primary education or less. 'Supporting redistribution' equals the values 4 or 5 of our redistribution variable. 
Regarding preferences for activation, we hypothesized that the effect would become stronger with increasing skill levels because high-skilled outsiders should have particularly strong incentives to favor investment in human capital and jobs: what they want first and foremost is an opportunity to work. Hypothesis $2 \mathrm{a}$ is fully confirmed by the data: Model 4 indicates a positive and significant interaction effect for activation preferences. Figure 2 shows that the higher the educational level, the stronger labor market vulnerability affects preferences for activation. The predicted probabilities substantiate this finding: the likelihood of an individual with the highest degree of outsiderness and tertiary education to strongly support activation (a score of 7 or more on a scale from 0 to 10 ) is $52 \%$, while the same individual exposed to the lowest degree of labor market vulnerability has only a $36.3 \%$ chance to strongly support activation. The difference between a low-skilled individual with highest and lowest degree of labor market vulnerability is around 15.9 percentage points.

To reiterate, we expect preferences for social insurance to be particularly strong among highskilled insiders (H2c). Although social insurance is relatively unattractive for all low-skilled in account of their inherently low contributions, the higher the human capital of a respondent, the stronger we expect the marginal effect of vulnerability to be. We therefore expect the insider/ outsider divide to widen with increasing levels of education. Figure 2 confirms this interaction effect graphically. The results corroborate our theoretical reasoning: high-skilled insiders support the equivalence principle more strongly than high-skilled outsiders. A high-skilled insider (lowest degree of outsiderness) has a likelihood of $81.9 \%$ of agreeing that individuals with higher contribution records should receive larger old-age pension benefits. For the same individual being an outsider (highest degree of labor market vulnerability), this probability is 15 percentage points lower.

To conclude our analysis, we examine the relative impact of education and labor market vulnerability on social policy preferences. Table 5 reports the predicted probabilities of an average individual at lowest (primary education or less) and highest (tertiary education) level of education to support each of the three distributive principles, compared with the same individual at minimum and maximum values of labor market vulnerability. We find that differences between low and highly educated respondents are much smaller than differences between individuals with

Table 5 Predicted probabilities for social policy support

\begin{tabular}{|c|c|c|c|}
\hline \multicolumn{4}{|c|}{ Predicted probability to support redistribution } \\
\hline Low skill levels & 67.6 & Max. outsiderness & 72.7 \\
\hline \multirow[t]{2}{*}{ High skill levels } & 56.8 & Min. outsiderness & 54.2 \\
\hline & 10.8 & & 18.5 \\
\hline \multicolumn{4}{|c|}{ Predicted probability to support job creation } \\
\hline Low skill levels & 52.2 & Max. outsiderness & 60.1 \\
\hline \multirow[t]{2}{*}{ High skill levels } & 44 & Min. outsiderness & 39.9 \\
\hline & 8.2 & & 20.2 \\
\hline \multicolumn{4}{|c|}{ Predicted probability to social insurance } \\
\hline Low skill levels & 64.8 & Max. outsiderness & 61.7 \\
\hline \multirow[t]{2}{*}{ High skill levels } & 75.7 & Min. outsiderness & 76 \\
\hline & -10.9 & & -14.3 \\
\hline
\end{tabular}

Data source: ESS 42008. 
the lowest and highest value of outsiderness with regard to all three social policy preferences. The importance of labor market vulnerability for social policy preferences is striking: differences in predicted probabilities between individuals with highest and lowest values of labor market vulnerability are around 16 percentage points, and differences between individuals with highest and lowest levels of education range between 8.4 and 13.1 percentage points. The same analyses calculated for different model specifications of the average individual (different countries, men instead of women and different ages) lead to the same conclusion that the degree of labor market vulnerability is more important for social policy preferences than the level of education.

\section{Conclusion}

Increasing divides between labor market insiders and outsiders concern policy makers and academic scholars alike. Although labor market vulnerability is often seen as a phenomenon that affects the low-skilled segment of the labor market, this article demonstrates that dualization and educational attainment are not collinear phenomena. Rather, labor market vulnerability spreads well into highly educated segments of the population with striking implications for the preference formation of both high- and low-skilled outsiders.

We have shown that high-skilled women experience an over-proportional risk of temporary or involuntary part-time work, while the labor market vulnerability of highly educated young labor market participants results mainly from temporary work. We also produced clear evidence that labor market vulnerability is linked to an inferior labor market status even for the highly educated. High-skilled outsiders experience lower job satisfaction and income security than do high- skilled individuals with low labor market vulnerability. Hence, atypical work among the high-skilled is not just an unproblematic, deliberate choice they make. Labor market vulnerability leads both individuals with lower and higher education levels to fear that they might easily be replaced and lowers their chances to improve their skills. Our evidence suggests that labor market vulnerability is associated with stronger preferences for redistribution and activation but lower support for social insurance. Regarding the joint effect of labor market risks and education, highly educated outsiders are cross-pressured when it comes to social policy preferences. Their high level of human capital would predispose the high-skilled to oppose redistribution and activation and instead favor social insurance, while their labor market vulnerability pushes their preferences in the opposite directions. Comparing the relative importance of education and labor market vulnerability, we conclude that the effect of labor market vulnerability on social policy preferences exceeds the one of education.

Our findings contribute to the literature on insider/outsider divides, comparative political economy as well as social policy preferences and welfare support. First, our analysis underscores the importance of distinguishing between different distributive principles of social policy. We clearly need to study insider/outsider preferences with regard to specific distributive policies, because different welfare policies affect them in distinct ways. Just as large welfare states do not need to be redistributive welfare states at the macro-level (Esping-Andersen, 1990; Huber and Stephens, 2001), welfare state preferences on the individual level are not to be equated with preferences for 'more' or 'less' welfare state (Moene and Wallerstein, 2003; Fernàndez-Albertos and Manzano, 2011) as distinct policies have different distributive consequences for different social groups.

Second, the findings emphasize the importance of treating labor market vulnerability and education levels as two separate dimensions in determining individuals' labor market position. 
Most important, our article has important implications for the insider/outsider literature and the study of welfare state support. High-skilled outsiders are a cross-pressured group: while they possess a high earning potential, their labor market vulnerability prevents them from capitalizing on this earning potential. Our analysis indicates that labor market vulnerability is particularly relevant for explaining the preferences of precisely these individuals. For them, the effect of labor market vulnerability prevails over the effect of the positive prospects of being highly qualified.

Our findings therefore point to the potential of cross-class alliances between highly and lower skilled vulnerable individuals in support of a redistributive and activating welfare state. This has far-reaching implications for our understanding of both the politicization of insider/outsider divides and the politics of welfare support. In contrast to low-skilled outsiders, higher skilled outsiders are likely to be a politically informed and active group (Häusermann and Schwander, 2012), which is why insider/outsider divides are more likely to become politicized once higher skilled individuals are affected, too. In addition, besides enlarging the pro-redistribution and pro-activation coalition, their preferences should weight more strongly in the politics of welfare state reforms, given the stronger political mobilization of more high-skilled groups. Yet further research needs to explore the conditions under which such a cross-class alliance emerges at the macro-level and whether these social policy preferences are translated into political processes. What this article provides is a micro-foundation of potential dynamics in welfare politics, the realization of which depends on the organization and mobilization efforts of political organizations.

\section{Supplementary material}

Supplementary material is available at SOCECO online.

\section{Acknowledgements}

Earlier versions of the article have been presented at the Conference of Europeanists 2010 in Montréal, the Oxford/Sciences Po joint doctoral seminar 'The Dynamics of Politics and Inequalities' 2011 in Paris and the 'workshop for welfare state analysis' in Odense, 2013. We thank John D. Stephens, Nonna Meyer, Elias Naumann, Marius Busemeyer and the participants of these conferences for their valuable comments.

\section{Funding}

This work benefited from generous funding from the Swiss National Science Foundation (research grant nr. 100017 131994/1).

\section{References}

Autor, D. H., Levy, F. and Murnane, R. J. (2003) 'The Skill Content of Recent Technological Change: An Empirical Exploration', Quarterly Journal of Economics, 118, 1279-1333.

Bénabou, R. and Tirole, J. (2006) 'Belief in a Just World and Redistributive Politics', Quarterly Journal of Economics, 121, 699-746. 
Blanchflower, D. G. and Freeman, R. B. (2000) 'The Declining Economic Status of Young Workers in OECD Countries'. In Blanchflower, D. G. and Freeman, R. B. (eds) Youth Employment and Joblessness in Advanced Countries, Chicago, NBER and University of Chicago Press.

Bonoli, G. (2005) 'The Politics of the New Social Policies: Providing Coverage against New Social Risks in Mature Welfare States', Policy \& Politics, 33, 431-449.

Bonoli, G. (2013) Origins of Active Social Policy: Labour Market and Childcare Polices in a Comparative Perspective, Oxford, Oxford University Press.

Bonoli, G. and Natali, D. (2012) The Politics of the 'New' Welfare States, Oxford, Oxford University Press.

Carbonaro, W. (2007) 'The Effects of Education and Cognitive Skill on Earnings: How Much Do Occupations and Jobs Matter?', Research in Social Stratification and Mobility, 25, 57-71.

Chauvel, L. (2009) 'Comparing Welfare Regime Changes: Living Standards and the Unequal Life Chances of Different Birth Cohorts'. In Rees Jones, I., Paul Higgs, P. and Ekerdt, D. J. (eds) Consumption and Generational Change: The Rise of Consumer Lifestyles, New Brunswick, NJ, Transaction Publishers, pp. 229-273.

Couppié, T. and Mansuy, M. (2003) 'Young People and New Entrants in European Labour Markets: The Timing of Gradual Integration'. In Müller, W. and Gangl, M. (eds) Transitions from Education to Work in Europe: The Integration of Youth into EU Labour Markets, Oxford, Oxford University Press, pp. 63-106.

Crouch, C. (1999) Social Change in Western Europe, Oxford, Oxford University Press.

De La O, A. L. and Rodden, J. A. (2008) 'Does Religion Distract the Poor? Income and Issue Voting around the World', Comparative Political Studies, 41, 437-476.

Emmenegger, P. (2009) 'Specificity vs. Replaceability: The Relationship between Skills and Preferences for Job Security Regulations', Socio-Economic Review, 7, 407-430.

Emmenegger, P. and Careja, R. (2012) 'From Dilemma to Dualisation. Social and Migration Policies in the 'Reluctant Countries of Immigration'. In Emmenegger, P., Häusermann, S., Palier, B. and Seeleib-Kaiser, M. (eds) The Age of Dualization: The Changing Face of Inequality in Deindustrializing Societies, New York, Oxford University Press, pp. 124-148.

Emmenegger, P., Häusermann, S., Palier, B. and Seeleib-Kaiser, M. (2012) The Age of Dualization: The Changing Face of Inequality in Deindustrializing Societies, New York, Oxford University Press.

Esping-Andersen, G. (1990) The Three Worlds of Welfare Capitalism, Princeton, NJ, Princeton University Press.

Esping-Andersen, G. (1999) The Social Foundation of Postindustrial Economies, Princeton, NJ, Princeton University Press.

Esping-Andersen, G. (2009) The Incomplete Revolution: Adapting Welfare States to Women "s New Roles, Cambridge, MA, Polity Press.

Fellini, I. and Migliavacca, M. (2010) 'Unstable Employment in Europe: Exploring the Individual and Household Dimensions'. In Ranci, C. (ed.) Social Vulnerability in Europe: The New Configuration of Social Risks, Basingstoke, Palgrave Macmillan, pp. 88-125.

Fernàndez-Albertos, J. and Manzano, D. (2011) 'Redstribution Preferences and Welfare State Support: The Role of Dualism in the Labor Market', paper presented at the Annual Meeting of the American Political Science Association, Seatle, 2011.

Gangl, M. (2001) 'European Patterns of Labour Market Entry. A Dichotomy of Occupationalized vs. Non-Occupationalized Systems?', European Societies, 3, 471-494.

Gangl, M. (2003) 'The Only Way Is Up?: Employment Protection and Job Mobility among Recent Entrants to European Labour Markets', European Sociological Review, 19, 429-449.

Gelissen, J. (2000) 'Popular Support for Institutionalised Solidarity: A Comparison between European Welfare States', International Journal of Social Welfare, 9, 285-300. 
Goldthorpe, J. H. (2000) On Sociology. Numbers, Narratives, and the Integration of Research and Theory, New York, Oxford University Press.

Goos, M. and Manning, A. (2007) 'Lousy and Lovely Jobs: The Rising Polarization of Work in Britain', Review of Economics and Statistics, 89, 118-133.

Häusermann, S. and Schwander, H. (2011) 'Who Are the Outsider and What Do They Want? Welfare State Preferences in Dualized Societies', Les Cahiers Européens de Sciences Po, no. 01.

Häusermann, S. and Schwander, H. (2012) 'Varieties of Dualization? Labor Market Segmentation and Insider-Outsider Divides across Regimes'. In Emmenegger, P., Häusermann, S., Palier, B. and Seeleib-Kaiser, M. (eds) The Age of Dualization: The Changing Face of Inequality in Deindustrializing Societies, New York, Oxford University Press, pp. 27-51.

Huber, E. and Stephens, J. D. (2001) Development and Crisis of the Welfare State: Parties and Policies in Global Markets, Chicago, University of Chicago Press.

Inglehart, R. (1977) The Silent Revolution: Changing Values and Political Styles among Western Publics, Princeton, NJ, Princeton University Press.

Jaeger, M. M. (2006) 'Welfare Regimes and Attitudes towards Redistribution: The Regime Hypothesis Revisited', European Sociological Review, 22, 157-170.

King, D. and Rueda, D. (2008) 'Cheap Labor: The New Politics of "Bread and Roses” in Industrial Democracies', Perspectives on Politics, 6, 279-297.

Kitschelt, H. and Rehm, P. (forthcoming) 'Occupations as a Site of Political Preference Formation', Comparative Political Studies.

Kriesi, H. (1993) Political Mobilization and Social Change: The Dutch Case in Comparative Perspective, Aldershot, Avebury.

Lindbeck, A. and Snower, D. J. (2001) 'Insiders versus Outsiders', Journal of Economic Perspectives, 15, 165-188.

Linos, K. and West, M. (2003) 'Self-Interest, Social Beliefs, and Attitudes to Redistribution: Re-Addressing the Issue of Cross-National Variation', European Sociological Review, 19, 393-409.

Margalit, Y. M. (2013) 'Explaining Social Policy Preferences: Evidence from the Great Recession', American Political Science Review, 107, 80-103.

Meltzer, A. H. and Richard, S. F. (1981) 'A Rational Theory of the Size of Government', Journal of Political Economy, 89, 914-928.

Moene, K. O. and Wallerstein, M. (2001) 'Inequality, Social Insurance, and Redistribution', American Political Science Review, 95, 859-874.

Moene, K. O. and Wallerstein, M. (2003) 'Earning Inequalities and Welfare Spending: A Disaggregated Analysis', World Politics, 55, 485-516.

Müller, W. (1999) 'Class Cleavages in Party Preferences in Germany_Old and New'. In Evans, G. (ed) The End of Class Politics, Oxford, Oxford University Press.

Murnane, R. J., Willett, J. B. and Levy, F. (1995) 'The Growing Importance of Cognitive Skills in Wage Determination', Review of Economics and Statistics, 77, 251-266.

OECD (2012) 'Statextracts', http://stats.oecd.org/Index.aspx?QueryId=38900 [accessed March 17, 2014].

Oesch, D. (2006) Redrawing the Class Map: Stratification and Institutions in Britain, Germany, Sweden and Switzerland, Basingstoke, Palgrave Macmillan.

Oesch, D. and Rodriguez Menes, J. (2011) 'Upgrading or Polarization? Occupational Change in Britain, Germany, Spain and Switzerland, 1990-2008', Socio-Economic Review, 9, 503-531.

O'Reilly, J. and Fagan, C. (1998) Part-Time Prospects: International Comparisons of Part-Time Work in Europe, North America and the Pacific Rim, London, Routledge.

Palier, B. (2002) 'From Crisis to Reforms in the Welfare State-the French Example in Compared Perspective', Revue Francaise de Sociologie, 43, 243. 
Palier, B. and Thelen, K. A. (2010) 'Institutionalizing Dualism: Complementaries and Change in France and Germany', Politics \& Societies, 38, 119-148.

Piore, M. J. (1980) 'An Economic Approach'. In Berger, S. and Piore, M. J. (eds) Dualism and Discontinuity in Industrial Societies, Cambridge, Cambridge University Press.

Polavieja, J. G. (2006) 'The Incidence of Temporary Employment in Advanced Economies: Why Is Spain Different?', European Sociological Review, 22, 61-78.

Pozzoli, D. (2009) 'The Transition to Work for Italian University Graduates', Labour, 23, 131-169.

Ranci, C. (2010) Social Vulnerability in Europe: The New Configuration of Social Risks, Basingstoke, Palgrave Macmillan.

Regini, M. (2000) 'Between Deregulation and Social Pacts: The Responses of European Economies to Globalization', Politics \& Society, 28, 5-33.

Rehm, P. (2009) 'Risks and Redistribution', Comparative Political Studies, 42, 855-881.

Rehm, P. (2011a) 'Risk Inequality and the Polarized American Electorate', British Journal of Political Science, 41, 363-387.

Rehm, P. (2011b) 'Social Policy by Popular Demands', World Politics, 63, 271-299.

Rehm, P. and Kitschelt, H. (2005) 'Work, Family and Politics. Foundations of Electoral Partisan Alignments in Postindustrial Democracies', paper presented at Annual Meeting of the American Political Science Association, Washington, DC, September 1-4.

Rehm, P., Hacker, J. S. and Schlesinger, M. (2012) 'Insecure Alliances: Risk, Inequality, and Support for the Welfare State', American Political Science Review, 106, 386-406.

Rueda, D. (2005) 'Insider-Outsider Politics in Industrialized Democracies: The Challenge to Social Democratic Parties', American Political Science Review, 99, 61-74.

Rueda, D. (2006) 'Social Democracy and Active Labour-Market Policies: Insiders, Outsiders and the Politics of Employment Protection', British Journal of Political Science, 36, 385-406.

Rueda, D. (2007) Social Democracy Inside Out: Partisanship and Labor Market Policy in Industrialized Democracies, Oxford, Oxford University Press.

Scarpetta, S. (1996) 'Assessing the Role of Labor Market Policies and Institutional Setting on Unemployment: A Gross-Country Study', OECD Economic Studies, 26, 44-99.

Scheepers, P. and Grotenhuis, M. T. (2005) 'Who Cares for the Poor in Europe?: Micro and Macro Determinants for Alleviating Poverty in 15 European Countries', European Sociological Review, 21, 453-465.

Scheve, K. and Stasavage, D. (2006) 'Religion and Preferences for Social Insurance', Quarterly Journal of Political Science, 1, 255-286.

Schwander, H. and Häusermann, S. (2013) 'Who's In and Who's Out? A Risk-Based Conceptualisation of Insiders and Outsiders', Journal of European Social Policy, 23, 248-269.

Shavit, Y. and Müller, W. (1998) From School to Work: A Comparative Study of Educational Qualifications and Occupational Destinations, Oxford, Clarendon Press.

Taylor-Gooby, P. (2005) New Risks, New Welfare: The Transformation of the European Welfare State, Oxford, Oxford University Press.

van Oorschot, W. (2006) 'Making the Difference in Social Europe: Deservingness Perceptions among Citizens of European Welfare States', Journal of European Social Policy, 16, 23-42.

Walter, S. (2010) 'Globalization and the Welfare State: Testing the Microfoundations of the Compensation Hypothesis', International Studies Quarterly, 54, 403-426.

World Bank (2013) 'http://data.worldbank.org/Indicator/Sl.Uem.1524.Zs'. 